\title{
ВЛИЯНИЕ СИСТЕМ ЗЕМЛЕДЕЛИЯ НА ПОКАЗАТЕЛИ ОБИЛИЯ СОРНЫХ РАСТЕНИЙ И УРОЖАЙНОСТЬ КУКУРУЗЫ
}

\author{
Е.В. Носкова \\ к.С.-х.н., агроном-исследователь научно-исследовательской \\ лаборатории ресурсосберегающих технологий \\ ФГБОУ ВО Ярославская ГСХА, г. Ярославль
}

Кукуруза - это ценная кормовая культура в Центральном районе Нечернозёмной зоны РФ с высокой концентрацией обменной энергии, богата легкодоступными и легкопереваримыми биологически активными веществами. Получение максимально возможных её урожаев в регионе будет способствовать повышению продуктивности растениеводства и животноводства $[1,2,3]$. Минеральные и органические удобрения - одно из важных средств повышения урожайности

Система земледелия, показатель обилия сорных растений, урожайность кукурузы

Farming systems, weedage abundance measures, maize yields и качества сельскохозяйственных культур. Целью исследований было выявить оптимальную систему земледелия под данную культуру.

\section{Условия и методы исследований}

Экспериментальная работа проводилась на опытном поле Ярославского НИИЖК - филиала ФГБНУ «Федеральный научный центр кормопроизводства и агроэкологии им. В.Р. Вильямса», расположенном в посёлке Михайловское Ярославского района Ярославской области. Изучалось действие разных по интенсивности систем земледелия на структуру сорного компонента агрофитоценоза и урожайность зелёной массы кукурузы сорта Каскад 195.

\section{Системы земледелия:}

1. Контроль (К) - без удобрений.

2. Органо-минеральная (ОМ) - 60 т/га навоза под зяблевую вспашку, минеральные удобрения $\mathrm{N}_{100} \mathrm{P}_{100} \mathrm{~K}_{120}$.

3. Биологизированная (Б) - основана на биологических факторах с ограниченным применением минеральных удобрений. Основная роль принадлежит культурам семейства бобовых, сидератам и органическим удобрениям (60 т/га навоза под зяблевую вспашку и $\left.\mathrm{N}_{50} \mathrm{P}_{50} \mathrm{~K}_{60}\right)$.

4. Органическая (O) - без минеральных удобрений. В качестве органических удобрений используются сидераты (рожь, поукосно рапс) и последний укос многолетних трав.

Учёт сорных растений проводили по методике Б.А. Смирнова и В.И. Смирновой [4]. Для учёта многолетних сорных растений использовались рамки $1 \mathrm{M}^{2}(1 \mathrm{M} \times 1 \mathrm{M})$, а для учёта малолетних видов 1/16 $\mathrm{M}^{2}$ $(0,25 \mathrm{~m} \times 0,25$ м). Учётные площадки выделяли методом рендомизации. Урожайность учитывалась сплошным поделяночным методом, определялась при фактической влажности зелёной массы. 


\section{Результаты исследований}

Вегетационный период 2017 года отличался дождливым и прохладным летом (табл. 1). Погодные условия были неблагоприятными для роста и развития культур.

В среднем за вегетацию кукурузы на контроле встречалось 7 видов многолетних сорных ра- стений (табл. 2). Доля участия многолетних видов составила 26,5\%. В посевах преобладали пырей ползучий $(13,6 \%)$, осот полевой $(5,5 \%)$ и бодяк полевой $(4,1 \%)$.

Применение органоминеральных удобрений в полной дозе (ОМ) способствовало снижению доли участия многолетних видов до 15,4\%. В по-

Таблица 1 - Метеорологические условия вегетационного периода (по данным метеослужбы г. Ярославля)

\begin{tabular}{|l|c|c|c|c|c|}
\hline \multirow{2}{*}{\multicolumn{1}{|c|}{ Показатель }} & \multicolumn{5}{|c|}{ Месяц года } \\
\cline { 2 - 6 } & Май & Июнь & Июль & Август & Сентябрь \\
\hline Температура 2017 года, ${ }^{\circ} \mathrm{C}$ & 9,2 & 13,6 & 17,3 & 17,7 & 11,7 \\
\hline $\begin{array}{l}\text { Среднемноголетняя } \\
\text { температура, }{ }^{\circ} \mathrm{C}\end{array}$ & 11,3 & 15,6 & 17,7 & 15,7 & 9,9 \\
\hline $\begin{array}{l}\text { Сумма атмосферных осадков } \\
2017 \text { года, мм }\end{array}$ & 43 & 96 & 99 & 18 & 62 \\
\hline $\begin{array}{l}\text { Среднемноголетняя сумма } \\
\text { осадков, мм }\end{array}$ & 53 & 68 & 85 & 63 & 56 \\
\hline
\end{tabular}

севах на данном варианте встречалось 8 видов многолетников. Преобладали такие виды, как пырей ползучий $(8,4 \%)$, чистец болотный $(3,5 \%)$ и осот полевой (3,0\%). Таким образом, на удобренном фоне происходит снижение доли участия пырея ползучего на 5,2\%, осота полевого - на 3,5\%, бодяка полевого - на 3,5\%, повышение доли участия чистеца болотного - на 1,6\%.

Внесение органоминеральных удобрений в сниженной дозе (Б) также содействовало уменьшению доли участия многолетников до 15,0\%.
В посевах встречалось 6 видов, преобладали пырей ползучий $(6,9 \%)$, осот полевой $(2,7 \%)$ и бодяк полевой (2,6\%). На данном варианте происходит снижение доли участия пырея ползучего на $6,7 \%$, осота полевого - на 2,8\% и бодяка полевого - на 1,5\%.

Наибольшая доля участия в структуре сообщества многолетних видов сорных растений отмечалась по фону органических удобрений (5-O) и составила $39,8 \%$. В посевах встречалось 8 видов многолетних сорняков. Преобладали такие виды,

Таблица 2 - Видовой состав многолетних сорных растений в посевах кукурузы

\begin{tabular}{|l|c|c|c|c|}
\hline \multirow{2}{*}{\multicolumn{1}{|c|}{ Вид сорных растений }} & \multicolumn{4}{|c|}{ Система земледелия } \\
\cline { 2 - 5 } & K & ОМ & Б & O \\
\hline Всего, шт./м & 90,5 & 121,5 & 81,5 & 93,3 \\
\hline Всего многолетников, \% & 26,5 & 15,4 & 15,0 & 39,8 \\
\hline $\begin{array}{l}\text { В том числе: } \\
\text { Бодяк полевой }\end{array}$ & 4,1 & 0,6 & 2,6 & 0,5 \\
\hline Вьюнок полевой & 0 & 0,2 & 0 & 0 \\
\hline Лютик ползучий & 0,7 & 0,3 & 0,6 & 1,3 \\
\hline Одуванчик лекарственный & 0,9 & 0,6 & 0 & 0,5 \\
\hline Осот полевой & 5,5 & 2,0 & 2,7 & 9,2 \\
\hline Подорожник большой & 0,3 & 0 & 0 & 0,3 \\
\hline Пырей ползучий & 13,6 & 8,4 & 6,9 & 16,8 \\
\hline Хвощ полевой & 0 & 0 & 0,9 & 5,6 \\
\hline Чистец болотный & 1,4 & 3,0 & 1,3 & 5,6 \\
\hline Щавель курчавый & 0 & 0,3 & 0 & 0 \\
\hline
\end{tabular}


как пырей ползучий (16,8\%), осот полевой $(9,2 \%)$, хвощ полевой $(5,6 \%)$ и чистец болотный $(5,6 \%)$. Отмечается увеличение доли участия пырея ползучего, осота полевого, хвоща полевого и чистеца болотного, снижение - бодяка полевого.

В посевах кукурузы видовой состав малолетних сорных растений был представлен 13 видами (табл. 3). Доля участия малолетних видов в структуре сообщества сорных растений на контроле составила 73,5\%. Видовой состав представлен 8-ю видами. Постоянно присутствовали такие виды, как марь белая (32,4\%), горец шероховатый $(14,7 \%)$ и ромашка непахучая $(7,4 \%)$.

Наибольшая доля участия малолетних видов сорных растений отмечалась по биологизированному фону (Б) и составила 85,0\%, а наименьшая - по фону органических удобрений (5-0) $60,2 \%$. По всем фонам удобрений преобладали

Таблица 3 - Видовой состав малолетних сорных растений в посевах кукурузы

\begin{tabular}{|c|c|c|c|c|}
\hline \multirow{2}{*}{ Вид сорных растений } & \multicolumn{4}{|c|}{ Система земледелия } \\
\hline & K & OM & 5 & $\mathrm{O}$ \\
\hline Всего, шт./м² & 90,5 & 121,5 & 81,5 & 93,3 \\
\hline Всего малолетников, \% & 73,5 & 84,6 & 85,0 & 60,2 \\
\hline $\begin{array}{l}\text { в том числе: } \\
\text { Горец вьюнковый }\end{array}$ & 4,4 & 1,1 & 6,5 & 0 \\
\hline Горец шероховатый & 14,7 & 16,5 & 3,3 & 4,3 \\
\hline Звездчатка средняя & 0 & 1,1 & 9,8 & 11,5 \\
\hline Дымянка аптечная & 5,9 & 3,3 & 8,2 & 11,5 \\
\hline Марь белая & 32,4 & 32,9 & 27,9 & 15,7 \\
\hline Незабудка полевая & 0 & 0 & 0 & 1,4 \\
\hline Пикульник красивый & 1,4 & 2,2 & 0 & 2,9 \\
\hline Подмаренник цепкий & 0 & 2,2 & 6,5 & 0 \\
\hline Ромашка непахучая & 7,4 & 10,0 & 9,8 & 8,6 \\
\hline Сушеница топяная & 0 & 0 & 1,6 & 0 \\
\hline Торица полевая & 1,4 & 7,6 & 0 & 0 \\
\hline Ярутка полевая & 5,9 & 5,5 & 9,8 & 1,4 \\
\hline Яснотка пурпуровая & 0 & 2,2 & 1,6 & 2,9 \\
\hline
\end{tabular}

марь белая и ромашка непахучая. В единичных экземплярах встречалась сушеница топяная по биологизированному фону (4-Б). Наибольшее число видов малолетников (11) отмечается на органоминеральном фоне с полной дозой удобрений (ОМ). На биологизированном фоне (Б) со сниженной дозой увеличивалась доля участия звездчатки средней, ярутки полевой и ромашки непахучей. Хорошо отзывались на органические удобрения (О) такие виды, как звездчатка средняя, дымянка аптечная, яснотка пурпуровая, незабудка полевая и пикульник красивый со снижением доли участия мари белой, горцев.

Урожайность кукурузы имела динамику увеличения при внесении разных видов удобрений (табл. 4). Наибольшая урожайность зелёной массы кукурузы отмечалась на фоне органоминеральных удобрений с полной дозой (ОМ) и составила
562 ц/га. При снижении дозы (Б) урожайность составила 331 ц/га, а без внесения удобрений - 143 ц/га. Система земледелия с органическим удобрением (O) не привела к повышению урожайности культуры. Наоборот, наблюдалось её снижение.

\section{Выводы}

Применение в посевах кукурузы органоминеральных удобрений с полной и сниженной дозой привело к уменьшению доли участия многолетних видов на 11,1 и 11,5\% соответственно, в сравнении с контролем. На данных фонах происходит снижение доли участия пырея ползучего на 5,2-6,7\%, осота полевого - на 2,8-3,5\%, бодяка полевого - на 1,5-3,5\%, повышение доли участия чистеца болотного на $1,6 \%$.

Внесение органических удобрений (сидератов, укосов многолетних трав) способствовало 
Таблица 4 - Урожайность зелёной массы кукурузы, ц/га

\begin{tabular}{|c|c|}
\hline Система земледелия & Урожайность, ц/га \\
\hline K & 143 \\
\hline OM & 562 \\
\hline Б & 331 \\
\hline O & 133 \\
\hline
\end{tabular}

повышению доли многолетников на 13,3\% в сравнении с контролем.

С использованием органической системы земледелия увеличивается доля участия хвоща полевого на $5,6 \%$, чистеца болотного - на $4,2 \%$, осота полевого - на 3,7\%, пырея ползучего - на 3,2\%; снижается доля участия бодяка полевого на 3,6\%.

Наибольшее число видов малолетних сорных растений (11 видов) отмечается при внесении органоминеральных удобрений с полной дозой.
Органическая система земледелия способствовала увеличению доли участия звездчатки средней, дымянки аптечной, яснотки пурпуровой, незабудки полевой, пикульника красивого и снижению доли мари белой, горцев.

Урожайность зелёной массы кукурузы повышалась при внесении органоминеральных удобрений в полной дозе на 419 ц/га в сравнении с контролем.

\section{Лumepamypa}

1. Семина, С.А. Влияние минеральных удобрений и густоты растений на параметры фотосинтеза и продуктивность кукурузы [Текст] / С.А. Семина, И.В. Гаврюшина, А.С. Палийчук // Земледелие. - 2017. № 4. - С. 15-18.

2. Усанова, 3.И. Влияние расчетных доз удобрений и густоты стояния на продуктивность кукурузы, вынос и хозяйственный баланс основных элементов питания [Текст] / 3.И. Усанова, И.В. Шальнов, А.С. Васильев // Земледелие. - 2016. - № 3. - С. 23-26.

3. Чекмарев, П.А. Влияние удобрений на пищевой режим почвы и химический состав зерна гибридов кукурузы [Текст] / П.А. Чекмарев, В.Н. Фомин, С.Л. Турнин // Земледелие. - 2017. - № 8. - С. 14-17.

4. Смирнов, Б.А. Методика учёта засорённости посевов в полевом опыте [Текст] / Б.А. Смирнов, В.И. Смирнова // Известия ТСХА. - 1976. - Вып. 224. - С. 4.

\section{References}

1. Semina, S.A. Vlijanie mineral'nyh udobrenij i gustoty rastenij na parametry fotosinteza i produktivnost' kukuruzy [Tekst] / S.A. Semina, I.V. Gavryushina, A.S. Palijchuk // Zemledelie. - 2017. - № 4. - S. 15-18.

2. Usanova, Z.I. Vlijanie raschetnyh doz udobrenij i gustoty stojanija na produktivnost' kukuruzy, vynos i hozjajstvennyj balans osnovnyh jelementov pitanija [Tekst] / Z.I. Usanova, I.V. Shal'nov, A.S. Vasil'ev // Zemledelie. - 2016. - № 3. - S. 23-26.

3. Chekmarev, P.A. Vlijanie udobrenij na pishhevoj rezhim pochvy i himicheskij sostav zerna gibridov kukuruzy [Tekst] / P.A. Chekmarev, V.N. Fomin, S.L. Turnin // Zemledelie. - 2017. - № 8. - S. 14-17.

4. Smirnov, B.A. Metodika uchjota zasorjonnosti posevov v polevom opyte [Tekst] / B.A. Smirnov, V.I. Smirnova // Izvestija TSHA. - 1976. - Vyp. 224. - S. 4. 